\title{
Analisis Pengaruh Sifat kemagnetan Bahan Seng Terhadap Medan Magnet Lokal di BMKG Tondano
}

\author{
Sutrisnawati Mehora \\ Universitas Sembilan Belas November Kolaka \\ e-mail: mehora21@gmail.com
}

\begin{abstract}
Abstrak
Pengaruh sifat kemagnetan bahan seng terhadap medan magnet lokal di Tondano merupakan suatu penelitian yang bertujuan untuk menganalisis pengaruh sifat bahan seng terhadap medan magnet lokal dan membutikan kebenaran konsep atau teori fisika tentang salah satu sifat kemagnetan bahan terhadap medan magnet bumi. Metode penelitian dimulai dengan pengambilan data absolut tanpa ada seng yang dijadikan sebagai pembanding dengan data yang diperoleh pada saat penelitian. Dalam penelitian dilakukan tiga pemodelan bahan seng yaitu model horizontal, model tegak lurus vertikal dan tegak lurus sejajar dengan variasi jarak dan menggunakan alat sensor yaitu proton precision magnetometer (PPM). Hasil dari penelitian menunjukkan grafik hubungan jarak dan medan magnet yang berbentuk ekponensial. Dari ketiga model persamaan ekponensial terlihat bahwa faktor luasan daerah dan tingkat peluruhan terhadap jarak mempengaruhi medan magnet lokal khususnya di stasiun Geofisika di Tondano, yang berarti bahwa bahan seng hanya merupakan suatu media untuk mengetahui karakter untuk mendeteksi sensor medan magnet yang sifatnya terinduksi oleh medan magnet lokal di daerah tersebut. Semakin luas daerah yang diteliti atau semakin jauh jarak suatu bahan seng terhadap sensor medan magnet maka, selisih terhadap terhadap medan magnet lokalnya akan semakin kecil atau perlahan-lahan akan hilang.
\end{abstract}

Kata-kata kunci: Sifat kemagnetan, Bahan Seng, Medan Magnet Lokal.

\section{PENDAHULUAN}

Pengamatan magnet bumi di Indonesia mulai dilakukan di Jakarta pada tahun 1866 oleh Koninklijk Magnetischen Meteorologish observatorium, pada saat pemerintahan kolonial belanda. Sistem peralatan yang digunakan untuk pengamatan pada saat itu masi menggunakan magnetograph foto. Untuk saat ini BMKG melakukan pengamatan fenomena kemagnetan bumi di 5 stasiun, yaitu stasiun geofisika Tangerang (1964), stasiun Geofisika Tuntungan di medan (1980), stasiun Geofiska di Tonadano (1990), dan dua stasiun lainnya baru mulai beroperasi akhir tahun 2006 yaitu stasiun Geofisika di Kupang dan stasiun Geofisika Bandung di Pelabuhan Ratu.

Metode untuk interpretasi data geomagnet dapat dilakukan dengan berbagai teori dan modeling. Metode geomagnet adalah suatu metode yang mempunyai prinsip yaitu memanfaatkan medan magnet bumi dan sifat kemagnet suatu benda/ batuan. Medan magnet merupakan ruang magnet ya didalamnya masi dirasakan adanya gaya magnet.

Menurut effendi (2009) kuat medan magnet yang terukur dipermukaan sebagian berasal dari dalam bumi (internal field) mencapai lebih dari 90\%, sedangkan sisanya adalah medan magnet dari kerak bumi, yang merupakan target di dalam eksplorasi Geofisika dan medan magnet dari luar bumi (external field). 
Penelitian mengenai medan magnet bumi dengan menggunakan pemodelan masih kurang dilakukan oleh badan meteorologi klimatologi dan geofisika di Indonesia khususnya di daerah Sulawesi utara. Oleh karena itu dengan kerjasama dan bantuan dari BMKG Winangun dan Tondano maka dilakukan suatu peneltian magnet bumi dengan menggunakan bahan seng untuk mengetahui sifat kemagnetan bahan tersebut terhadap pengaruh kemagnetannnya terhadap medan magnet bumi.

Sebagaimana yang diketahui bahwa kadar komposisi unsur seng di kerak bumi adalah sekitar 75 ppm $(0,007 \%)$ yang menjadikan seng sebagai unsur ke-24 yang paling melimpah di kerak bumi (Emsley 2001, p.503). Tanah mengandung sekitar 5-770 ppm seng dengan rata-rata $64 \mathrm{ppm}$, sedangkan pada air laut kadar sengnya adalah $30 \mathrm{ppm}$. Seng merupakan logam yang berwarna putih kebiruan, berkilau, dan bersifat diamagnetik, walu demikian, kebanyakan seng mutu komersial tidak berkilau.

Dalam penelitian ini menggunakan bahan seng karena seng(Zn) merupakan salah satu bahan diamagnetic yang sedikit menolak garis-garis medan magnet luar, Oleh karena itu perlunya analisis tentang sifat kemagnetan bahan seng untuk mengetahui tingkat pelurruhan bahan seng terhadap medan magnet lokal di Tondano. Seng digunakan dalam penelitian ini karena sifatnya yang masih terinduksi dan induksi seng mudah hilang. Pengukuran tingkat peluruhan medan magnet juga akan memberikan informasi tentang luasan disekitar pengukuran yang mampu terdeteksi oleh sensor.

\section{METODE PENELITIAN}

\subsection{Metode Penelitian dan Bagan Alir Penelitian}

Metode penelitian yang telah dilakukan adalah metode penelitian deskriptif jenis analisis survei (pengukuran langsung dilapangan) yang telah dilaksanakan pada bulan maret-april 2010 yang dilakukan di Stasiun Geofisika di Tondano dengan pengambilan data menggunakan alat dan bahan yaitu sensor Proton Procesion Magnetometer (PPM), Komputer, stopwatch, seng dan meteren.

Proses pengambilan data yang dilakukan yaitu dimulai dengan pengambilan data absolut (pengambilan data medan magnet tanpa ada seng yaitu dari tahun 2005-2010) yang di jadikan sebgai data pembanding dengan pengambilan data medan magnet dengan bahan seng. Selanjutnya menvariasikan model seng dengan menggunakan tiga pemodelan yaitu seng dengan model bidang horizontal, bidang vertikal sejajar, dan bidang vertical tegak lurus. Bahan seng yang digunakan awalnya ditanam di dalam tanah dengan kedalam $\pm 30 \mathrm{~cm}$ dengan menggunakan 1 buah seng dengan panjang dan lebar seng $\pm 6 \mathrm{~cm}$ dengan pengambilan 10 data tiap masing-masing jarak $0,5 \mathrm{~m}, 1 \mathrm{~m}, 1,5 \mathrm{~m}$ dan $2 \mathrm{~m}$ dari jarak sensor PPM. Data medan magnet yang dihasilkan akan ditampilkan oleh computer pembaca.

Sketsa pengukuran pengambilan data adalah sebagai berikut:

Posisi seng terhadap PPM

1. Model seng horizontal terhadap sensor

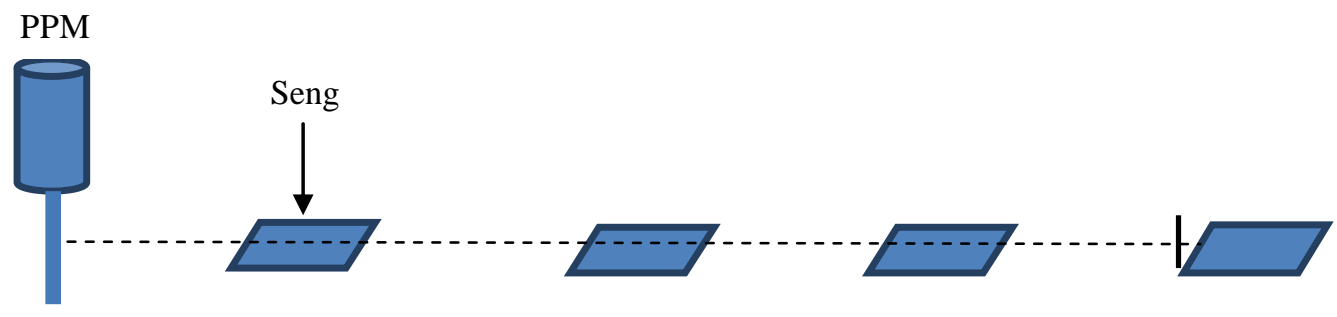


2. Model vertikal tegak lurus terhadap sensor

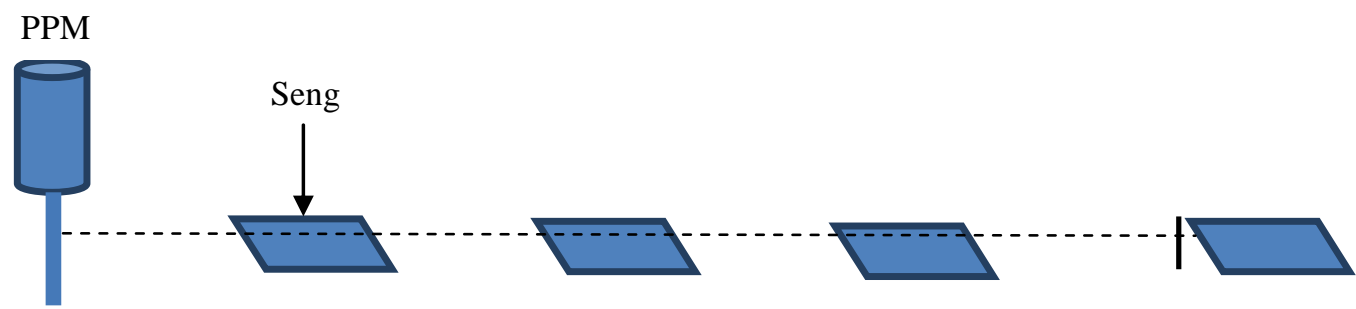

3. Model seng vertikal sejajar terhadap sensor

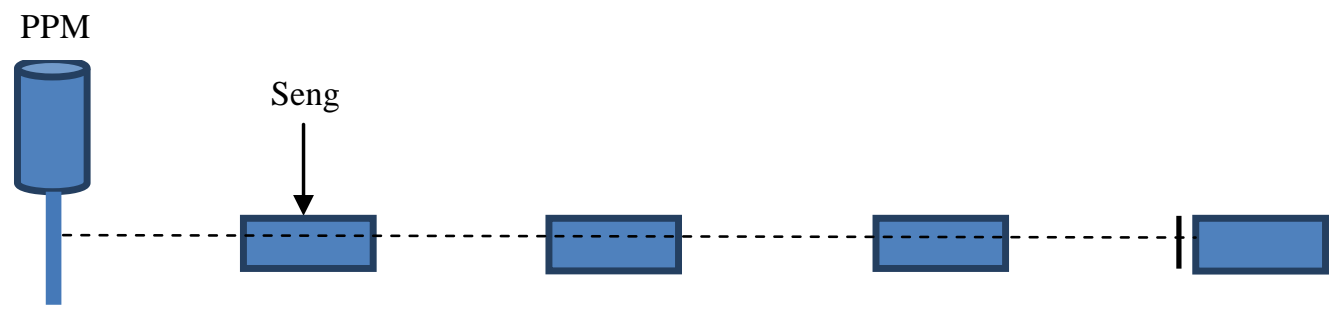

\subsection{Tinjauan Pustaka}

\subsubsection{Teori Magnet Bumi}

Secara fisis suatu bahan magnetik yang diletakkan dalam medan magnet $\mathrm{H}$ akan terimbas sesuai dengan medan tersebut. Akibatnya bahan itu sendiri akan timbul medan magnet $\mathrm{H}$ yang konsekuemsinya mengakibatkan pula bertambahnya kuat medan magnet total. Medan magnet baru ini erat hubungannya dengan intensitas kemagnetan yang menghasilkan perbandingan induksi magnetik (B) terhadap kuat magnetic $(\mathrm{H})$ yang disebut dengan permeabilitas magnetik. Adapun hubungan persamaan perbandingan tersebut yaitu:

$B=(1+4 \pi k) H=\mu$

Dalam magnet dikenal dua jenis kutub saja, kedua kutub tersebut juga memenuhi hokum Coulomb yang mana kutub sejenis saling tolak menolak dan kutub yang berlawanan akan tarik menarik. Gaya antara kutub-kutub akan sebanding dengan banyaknya masing-masing kutub serta berbandin terbalik dengan kuadrat jarak antara kedua kutub. Gaya magnet $(\mathrm{F})$ yang ditimbulkan olehkedua kutub yang berjarak (r) dengan dua buah kutub masing-masing $(\mathrm{m} 1)$ dan $(\mathrm{m} 2)$ dengan permeabilitas medium disekitarnya dirumuskan dengan persmaan:

$F=\frac{1}{\mu} \frac{m_{1} m_{2}}{r^{2}} \bar{r}_{1}$

Adapun hubungan antara kuat medan magnet $(\mathrm{H})$ pada suatu titik dengan jarak $(\mathrm{r})$ dari kutubnya adalah:

$H=\frac{m}{\mu r^{2}}$ atau $H=\frac{F}{m}$ 
Tingkat suatu bahan mampu dimagnetisasi ditentukan oleh suseptibilitas (kerentangan) kemagnetanya yang dirumuskan dengan persamaan:

$k=\frac{I}{H}$

Dengan $I$ adalah intensitas kemagnetan, $k$ adalah suseptibiltas magnet. Suseptibilitas merupakan parameter dasar yang dipergunakan dalam metode geomagnet. Respon kuantitatif data geomagnet sangat ditentukan oleh komposisi bahan atau mineralmineral yang bersifat magnetik dari batuan atau benda. Harga $\mathrm{k}$ akan semakin besar bila jumlah mineral-mineral magnetic semakin banyak.

\subsubsection{Metode Geomagnet dan bahan magnetik}

Metode Geofisika yang biasa dan umum digunakan untuk ekplorasi mineral atau benda adalah metode geomagnet. Metode untuk interprestasi data geomagnet dapat dilakukan dengan berbagai teori dan modeling. Pemodelan atau modeling dalam penelitian adalah suatu proses menvariasikan suatu posisi atau bentuk dari suatu bahan atau benda.

Dalam mengumpulkan data Geomagnet, ada banyak parameter yang perlu untuk diketahui antara lain lokasi tempat penyelidikan (yang melibatkan deklinasi, inklinasi, intesitas vertical dan intensitas horizontal), sifat-sifat fisis material (suseptibilitas) dan hal-hal lain yang berhubungan dengan kepekaan alat dan kejadian-kejadian terlepas dari pengamatan misalnya perubahan harian, badai matahari dan ketelitian dalam posisi alat selama pengukuran berlangsung. Intesitas medan magnet rata-rata dipermukaan bumi sekitar 0,5 oersted dalam satuan gama $(\gamma)$ besarnya $10^{-5}$ Oersted.

Penyelidikan geomagnet dapat diterapkan untuk mengetahui penyebaran dan bentuk tubuh-tubuh benda magnetic di bawah permukaan bumi selama masih terdapat kontras dalam kemagnetan dari material penyusunnya. Dalam penyelidikan geomagnet terdapat suatu metode yang dikenal dengan metode geomagnet. Metode geomagnet adalah suatu metode yang mempunyai prinsip yaiu memanfaatkan medan magnet bumi dan sifat kemagnetan suatu benda/ batuan. Kuat medan magnet yang terukur dipermukaan bumi sebagian besar berasal dari dalam bumi (internal field) yang mencapai $90 \%$, sedangkan sisanya adalah medan magnet dari kerak bumi yang merupakan target di dalam ekplorasi geofisika dan medan dari luar bumi (eksternal field).

Telford et al (1976) dalam penelitiannya menemukan medan magnet bumi yang diamati disuatu tempat merupakan resultan dari medan magnet bumi dan medan magnet yang ditmbulkan oleh variasi batuan pada masing-masing tempat. Medan magnet bumi yang diamati di suatu tempat merupakan resultan dari medan magnet bumi dan medan magnet yang ditimbulkan oleh variasi batuan pada masing-masing tempat.Harga medan magnet bumi total mempunyai nilai yang berbeda di masing-masing tempat.Nilai maksimumnya $70.000 \mathrm{nT}$ dan terletak dikutub magnet bumi utara dan $60.000 \mathrm{nT}$ terletak di kutub magnet bumi selatan, sedangkan nilai minimumnya $2.500 \mathrm{nT}$ terletak di sekitar equator bumi di Amerika selatan.

Secara sederhana kita dapat mengelompokkan bahan-bahan menjadi dua kelompok yaitu bahan magnetik (bahan yang dapat ditarik oleh magnet) dan bahan bukan magnetic ( bahan-bahan yang tidak dapat ditarik oleh magnet). Pada umunya ada tiga jenis bahan magnetik yang kita kenal yaitu pertama bahan yang paling kuat ditarik oleh oleh magnet adalah disebut bahan ferromagnetik contohnya besi,baja, dan nikel, bahan ini selain dapat ditarik dengan kuat oleh magnet juga dapat dibuat menjadi magnet. Kedua bahan yang dapat ditarik oleh magnet dengan lemah misalnya aluminium, platina dan mangan, sedangkan yang ketiga adalah bahan yang sedikit menolak garis-garis medan 
magnet luar dan dimagnetisasi arah kutubnya berlawanan dengan medan magnet dari luar yang disebut dengan bahan diamagnetic misalnya tembaga, seng,emas dan perak. Bahan diamagnetic dengan sendirinya tidak mengalami orientasi pemutaran di dalam medan magnet. Bahan diamagnet mempunyai sifat yaitu suseptibilitas $\mathrm{K}$ negative dan kecil. Suseptibiltitas K tidak tergantung pada medan magnet dari luar contohnya seperti bahan seng.

\subsubsection{Pengaruh gangguan (anomali) medan magnet pada pengukuran medan magnet bumi}

Mengetahui pengaruh magnetic dari berbagai benda di sekitar tempat pengamatan magnet bumi sangat penting karena benda magnetic dapat mempengaruhi harga pengukuran absolut oleh medan magnet bumi. Hal ini yang membedakan harga pengukuran di suatu tempat dengan tempat yang lain, Karena pada dasarnya harga medan magnet bumi bersifat regional yaitu mempunyai harga yang sama untuk semua daerah karena bumi dianggap homogen, dan yang membedakannya adalah benda magnetic yang ada disekitar tempat pengukuran medan magnet bumi baik diatas permukaan tanah maupun di bawah permukaan tanah (Jankowski dan Suckdorff,1966).

Penyebab utama penyimpangan medan magnet utama yang menghasilkan anomaly adalah karena perbedaan komposisi bahan yang bersifat magnetic yang berada di dekat permukaan. Berdasarkan sifat medan magnet bumi dan sifat kemagnetan bahan pembentuk batuan, maka bentuk medan magnet anomaly yang ditimbulkan oleh benda penyebabnya tergantung pada:

1. Inklinasi

2. Geometri benda penyebab

3. Kecenderungan arah dipol-dipol magnet di dalam benda penyebab

4. Orientasi arah dipol-dipol magnet benda penyebab terhadap arah medan magnet bumi.

Pengaruh benda magnetik dipengaruhi oleh beberapa parameter yaitu:

1. Jarak benda

2. Parameter magnetik dan volume benda

3. Bentuk geometri benda

4. Sudut antara komponen yang diukur dana rah megnetisasi benda

5. Sejarah masa lalu magnetik benda.

\section{HASIL DAN PEMBAHASAN}

\subsection{Proses Pengolahan Data}

Dalam menganalisis pengaruh sifat kemagnetan bahan seng terhadap medan magnet lokal khususnya di stasiun geofisika di Tondano di lakukan langka-langkah sebagai berikut:

1. Menghitung perubahan medan magnet lokal total rata-rata ( $\Delta \gamma_{\text {total }}$ rata-rata) pada tanggal 19-22 april dengan perumusan:

$\Delta \gamma_{\text {horizontal }}=\gamma$ rata-rata pada jarak r pada tanggal 19 april 2010- $\gamma_{\text {absolut total }}$ rata-rata pada tanggal 19 april (2005-2010).

$\Delta \gamma_{\text {vertical sejajar }}=\gamma$ rata-rata pada jarak r pada tanggal 22 april 2010- $\gamma_{\text {absolut total }}$ rata-rata pada tanggal 22 april (2005-2010).

$\Delta \gamma_{\text {vertical tegak lurus }}=\gamma$ rata-rata pada jarak r pada tanggal 22 april 2010- $\gamma_{\text {absolut total }}$ ratarata pada tanggal 22 april (2005-2010). 
2. Data-data yang diperoleh dari ketiga model seng tersebut kemudian digambarkan dalam bentuk grafik.

Untuk mengetahui besar perubahan yang sedang terjadi antara $\gamma$ rata-rata pada jarak $r$ dengan $\gamma$ total absolut (tahun pembanding) berdasarkan data yang diperolah pada table 1 dan 2, maka dapat dapat di hitung $\Delta \gamma$ total rata-rata untuk ketiga posisi model seng (posisi horizontal, posisi vertical sejajar, dan posisi vertical tegak lurus).

Tabel 1 Data magnet untuk medan magnet absolut pada tanggal 19 april mulai dari tahun 2005-2010 di Stasiun Geofisika di Tondano Sulawesi Utara

\begin{tabular}{|c|c|c|c|c|c|c|c|}
\hline \multirow[t]{2}{*}{ No } & \multicolumn{6}{|c|}{ Medan magnet absolut untuk tanggal 19 april (nT) } & \multirow{2}{*}{$\begin{array}{l}\text { Rata-rata } \\
\text { (nT) }\end{array}$} \\
\hline & 2005 & 2006 & 2007 & 2008 & 2009 & 2010 & \\
\hline 1 & 40499,1 & 40458,7 & 40474,5 & 40457,6 & 40413,8 & 40336,3 & 40439,99 \\
\hline 2 & 40499,2 & 40458,9 & 40474,7 & 40457,7 & 40412,1 & 40336,5 & 40439,8 \\
\hline 3 & 40499,7 & 40459,2 & 40475,2 & 40457,2 & 40412,4 & 40335,63 & 40439,89 \\
\hline 4 & 40499,7 & 40459,7 & 40475,5 & 40456,9 & 40412,2 & 40335,5 & 40439,91 \\
\hline 5 & 40500 & 40460 & 40476,1 & 40457,3 & 40491,6 & 40373,4 & 40459,73 \\
\hline 6 & 40500,2 & 40460,4 & 40476,4 & 40457,5 & 40412,4 & 40335,2 & 40457,51 \\
\hline 7 & 40500,5 & 40460,5 & 40477,1 & 40458 & 40361,4 & 40438,6 & 40437,67 \\
\hline 8 & 40500,7 & 40460,8 & 40477 & 40458,3 & 40411,9 & 40368,9 & 40441,61 \\
\hline 9 & 40500,9 & 40461,1 & 40476,5 & 40459 & 40412,2 & 40340,1 & 40441,96 \\
\hline 10 & 40501,3 & 40460,5 & 40476,4 & 40459,3 & 40412,1 & 40339,9 & 40439,76 \\
\hline $\begin{array}{l}\text { Rata- } \\
\text { rata }\end{array}$ & 40500,13 & 40460,08 & 40475,94 & 40457,88 & 40415,19 & 40354,70 & 40443,99 \\
\hline
\end{tabular}

Tabel 2 Data magnet untuk medan magnet absolut pada tanggal 22 april mulai dari tahun 2005-2010 di Stasiun Geofisika di Tondano Sulawesi Utara

\begin{tabular}{|c|c|c|c|c|c|c|c|}
\hline \multirow[t]{2}{*}{ No } & \multicolumn{6}{|c|}{ Medan magnet absolut untuk tanggal 22 april (nT) } & \multirow{2}{*}{$\begin{array}{l}\text { Rata-rata } \\
\text { (nT) }\end{array}$} \\
\hline & 2005 & 2006 & 2007 & 2008 & 2009 & 2010 & \\
\hline 1 & 40493,2 & 40487 & 40395,2 & 40366,5 & 40415,4 & 40320,5 & 40412,96 \\
\hline 2 & 40493,1 & 40487,3 & 40394,5 & 40366,9 & 40410,4 & 40320,5 & 40412,11 \\
\hline 3 & 40492,6 & 40486 & 40394,4 & 40366,9 & 40328,1 & 40319,2 & 40397,86 \\
\hline 4 & 40492,3 & 40484,9 & 40393,1 & 40367,5 & 40491,1 & 40321,6 & 40425,25 \\
\hline 5 & 40492,7 & 40483,4 & 40393,72 & 40367,86 & 40437,14 & 40323,53 & 40416,39 \\
\hline 6 & 40492,6 & 40482,4 & 40393,72 & 40367,87 & 40455,43 & 40320,33 & 40418,74 \\
\hline 7 & 40492,6 & 40482,3 & 40393,6 & 40368,2 & 40447,7 & 40323,5 & 40367,99 \\
\hline 8 & 40493 & 40482,4 & 40393,75 & 40368,33 & 40514,17 & 40320,54 & 40428,69 \\
\hline 9 & 40493,9 & 40482,1 & 40393,8 & 40368,3 & 40474,5 & 40320,8 & 40422,29 \\
\hline 10 & 40494,5 & 40481,8 & 40394,1 & 40368,9 & 40496,6 & 40320,5 & 40426,07 \\
\hline $\begin{array}{c}\text { Rata- } \\
\text { rata }\end{array}$ & 40493,05 & 40484,2 & 40394,09 & 40367,75 & 40417,06 & 40321,08 & 40412,84 \\
\hline
\end{tabular}

Tabel 3 Medan magnet model horizontal total

\begin{tabular}{|c|c|c|c|c|c|}
\hline No & $\begin{array}{l}\text { y untuk } r \\
=0.5 \mathrm{~m}\end{array}$ & $\begin{array}{l}\gamma \text { untuk } r \\
=1 \mathrm{~m}\end{array}$ & $\begin{array}{l}\gamma \text { untuk } r \\
=1.5 \mathrm{~m}\end{array}$ & $\begin{array}{l}\gamma \text { untuk } r \\
=2 \mathrm{~m}\end{array}$ & $\begin{array}{c}\text { Rata-rata } \\
(\mathrm{nT})\end{array}$ \\
\hline 1 & 40382,35 & 40341,78 & 40337,94 & 40336,19 & 40349,57 \\
\hline 2 & 40425,82 & 40341,88 & 40337,46 & 40337,03 & 40360,55 \\
\hline 3 & 40402,31 & 40343,3 & 40340,58 & 40337,54 & 40355,93 \\
\hline
\end{tabular}




\begin{tabular}{|c|c|c|c|c|c|}
\hline 4 & 40426,69 & 40341,83 & 40337,49 & 40335,78 & 40360,45 \\
\hline 5 & 40433,33 & 40343,71 & 40338,84 & 40338,04 & 40363,48 \\
\hline 6 & 40438,15 & 40342,1 & 40339,35 & 40335,76 & 40363,84 \\
\hline 7 & 40434,34 & 40343,99 & 40339,06 & 40334,59 & 40363 \\
\hline 8 & 40427,43 & 40342,91 & 40338,81 & 40335,9 & 40361,26 \\
\hline 9 & 40389,3 & 40342,04 & 40339,04 & 40336,93 & 40351,83 \\
\hline 10 & 40386,95 & 40337,94 & 40337,98 & 40338,08 & 40350,24 \\
\hline $\begin{array}{c}\text { Rata- } \\
\text { rata }\end{array}$ & 40414,667 & 40342,148 & 40338,655 & 40336,584 & 40358,01 \\
\hline
\end{tabular}

Tabel 4 Medan magnet model vertical tegak lurus total

\begin{tabular}{|c|c|c|c|c|c|}
\hline No & $\begin{array}{c}\gamma \text { untuk } r \\
=0.5 \mathrm{~m}\end{array}$ & $\begin{array}{l}\gamma \text { untuk } r \\
=1 \mathrm{~m}\end{array}$ & $\begin{array}{l}\gamma \text { untuk } r \\
=1.5 \mathrm{~m}\end{array}$ & $\begin{array}{l}\gamma \text { untuk } r \\
=2 \mathrm{~m}\end{array}$ & $\begin{array}{c}\text { Rata-rata } \\
(\mathrm{nT})\end{array}$ \\
\hline 1 & 40272,38 & 40328,78 & 40325,13 & 40327,1 & 40313,35 \\
\hline 2 & 40269,39 & 40325,16 & 40326,24 & 40326,46 & 40311,81 \\
\hline 3 & 40268,31 & 40326,46 & 40325,79 & 40324,76 & 40311,33 \\
\hline 4 & 40279,52 & 40327,85 & 40328,4 & 40324,99 & 40315,19 \\
\hline 5 & 40288,73 & 40330,9 & 40327,75 & 40327,27 & 40318,66 \\
\hline 6 & 40279,04 & 40332,14 & 40329,14 & 40326,44 & 40316,69 \\
\hline 7 & 40279,94 & 40328,93 & 40327,28 & 40326,21 & 40315,59 \\
\hline 8 & 40279,81 & 40330,22 & 40325,75 & 40324,51 & 40315,07 \\
\hline 9 & 40280,07 & 40330,07 & 40325,84 & 40324,7 & 40315,17 \\
\hline 10 & 40286,33 & 40329,96 & 40325,94 & 40325,44 & 40316,92 \\
\hline $\begin{array}{c}\text { Rata- } \\
\text { rata }\end{array}$ & 40278,352 & 40329,047 & 40326,726 & 40325,788 & 40314,98 \\
\hline
\end{tabular}

Tabel 5 Medan magnet model vertikal sejajar

\begin{tabular}{|c|c|c|c|c|c|}
\hline No & $\begin{array}{l}\gamma \text { untuk } r \\
=0.5 \mathrm{~m}\end{array}$ & $\begin{array}{l}\gamma \text { untuk } r \\
=1 \mathrm{~m}\end{array}$ & $\begin{array}{l}\gamma \text { untuk } \\
=1.5 \mathrm{~m}\end{array}$ & $\begin{array}{l}\gamma \text { untuk } r \\
=2 \mathrm{~m}\end{array}$ & $\begin{array}{c}\text { Rata-rata } \\
\text { (nT) }\end{array}$ \\
\hline 1 & 40422,7 & 40345,87 & 40333,17 & 40328,71 & 40357,61 \\
\hline 2 & 40423,48 & 40343,78 & 40333,7 & 40328,86 & 40357,37 \\
\hline 3 & 40419,73 & 40341,71 & 40331,4 & 40326,79 & 40354,91 \\
\hline 4 & 40424,73 & 40342,48 & 40332,72 & 40325,83 & 40356,44 \\
\hline 5 & 40418,47 & 40344,72 & 40333,31 & 40327,2 & 40355,93 \\
\hline 6 & 40425,4 & 40347,13 & 40332,19 & 40326,3 & 40357,76 \\
\hline 7 & 40435,74 & 40346,82 & 40331,85 & 40327,67 & 40360,52 \\
\hline 8 & 40428,53 & 40345,72 & 40331,72 & 40329,52 & 40358,87 \\
\hline 9 & 40423,42 & 40348,55 & 40332,1 & 40325,87 & 40357,49 \\
\hline 10 & 40421,98 & 40346,71 & 40332,65 & 40325,99 & 40356,83 \\
\hline $\begin{array}{c}\text { Rata- } \\
\text { rata }\end{array}$ & 40424,418 & 40345,349 & 40332,448 & 40327,274 & 40357,37 \\
\hline
\end{tabular}

Untuk mendapatkan $\Delta \gamma_{\text {horizontal }}, \Delta \gamma_{\text {vertical sejajar }}$, dan $\Delta \gamma_{\text {vertical tegak lurus }}$ maka secara umum digunakan persamaan-persamaan berikut:

\footnotetext{
$\Delta \gamma_{\text {horizontal }}=\bar{\gamma} *-\bar{\gamma} * *$

$\Delta \gamma_{\text {Vertikal tegak lurus }}=\bar{\gamma} *-\bar{\gamma} * *$

$\Delta \gamma_{\text {vertikal sejajar }}=\bar{\gamma} *-\bar{\gamma} * *$
} 
Dengan $\bar{\gamma} *$ adalah medan magnet rata-rata pada jarak $\mathrm{r}(\mathrm{nT})$ dan $\bar{\gamma} * *$ adalah medan magnet absolut total rata-rata (nT).Dengan menggunakan persamaan 5,6, dan 7 maka diperoleh tabel dan grafik untuk ketiga posisi seng dengan jarak dari sensor PPM yaitu:

Tabel 6 selisih medan magnet horizontal

\begin{tabular}{|c|c|c|c|c|}
\hline No & $\mathrm{r}(\mathrm{m})$ & $\begin{array}{c}\bar{\gamma} \text { pada jarak } r \\
(n T)\end{array}$ & $\begin{array}{c}\bar{\gamma}_{\text {absolut }} \text { total }(n T) \\
\text { rata-rata tahun 2005-2010 }\end{array}$ & $\begin{array}{c}\Delta \gamma_{\text {horizontal }} \\
(n T)\end{array}$ \\
\hline 1 & 0,5 & 40414,667 & 40443,99 & -29 \\
\hline 2 & 1 & 40342,148 & 40443,99 & -102 \\
\hline 3 & 1,5 & 40338,655 & 40443,99 & -105 \\
\hline 4 & 2 & 40336,584 & 40443,99 & -107 \\
\hline
\end{tabular}

Tabel 7 selisih medan magnet vertikal tegak lurus

\begin{tabular}{|c|c|c|c|c|}
\hline No & $\mathrm{r}(\mathrm{m})$ & $\begin{array}{c}\bar{\gamma} \text { pada jarak } r \\
(n T)\end{array}$ & $\begin{array}{c}\bar{\gamma}_{\text {absolut }} \text { total }(n T) \\
\text { rata-rata tahun } 2005-2010\end{array}$ & $\begin{array}{c}\Delta \gamma_{\text {vertikal tegak lurus }} \\
(n T)\end{array}$ \\
\hline 1 & 0,5 & 40424,418 & 40412,84 & 12 \\
\hline 2 & 1 & 40345,349 & 40412,84 & -67 \\
\hline 3 & 1,5 & 40332,448 & 40412,84 & -80 \\
\hline 4 & 2 & 40327,274 & 40412,84 & -86 \\
\hline
\end{tabular}

Tabel 8 selisih medan magnet vertikal sejajar

\begin{tabular}{|c|c|c|c|c|}
\hline No & $\mathrm{r}(\mathrm{m})$ & $\begin{array}{c}\bar{\gamma} \text { pada jarak } r \\
(n T)\end{array}$ & $\begin{array}{c}\bar{\gamma}_{\text {absolut }} \text { total }(n T) \\
\text { rata-rata tahun } 2005-2010\end{array}$ & $\Delta \gamma_{\text {vertikal sejajar }}(n T)$ \\
\hline 1 & 0,5 & 40278,352 & 40412,84 & -134 \\
\hline 2 & 1 & 40329,047 & 40412,84 & -84 \\
\hline 3 & 1,5 & 40326,726 & 40412,84 & -86 \\
\hline 4 & 2 & 40325,788 & 40412,84 & -87 \\
\hline
\end{tabular}

Tabel 9 perhitungan untuk selisih medan magnet horizontal

\begin{tabular}{|c|c|c|c|c|c|}
\hline No & $x$ & $y$ & $x^{2}$ & $y^{2}$ & $x y$ \\
\hline 1 & 0,5 & -26 & 0,25 & 662,0442212 & 13 \\
\hline 2 & 1 & -102 & 1 & 10371,3856 & 102 \\
\hline 3 & 1,5 & -105 & 2,25 & 11095,04089 & 157,5 \\
\hline 4 & 2 & -107 & 4 & 11535,61922 & 214 \\
\hline Jumlah & $\sum x_{i}=5$ & $\sum y_{i}=-340$ & $\sum x_{i}{ }^{2}=7,5$ & $\sum y_{i}{ }^{2}=33664,08993$ & $\sum x_{i} y_{i}=-486,5$ \\
\hline
\end{tabular}

Tabel 10 perhitungan untuk selisih medan magnet vertikal tegak lurus

\begin{tabular}{|c|c|c|c|c|c|}
\hline No & $x$ & $y$ & $x^{2}$ & $y^{2}$ & $x y$ \\
\hline 1 & 0,5 & 11 & 0,25 & 121 & -55 \\
\hline 2 & 1 & -67 & 1 & 4489 & -67 \\
\hline 3 & 1,5 & -80 & 2,25 & 6400 & -120 \\
\hline 4 & 2 & -86 & 4 & 7396 & -172 \\
\hline Jumlah & $\sum x_{i}=5$ & $\sum y_{i}=-222$ & $\sum x_{i}{ }^{2}=7,5$ & $\sum y_{i}{ }^{2}=18406$ & $\sum x_{i} y_{i}=-353,5$ \\
\hline
\end{tabular}

Tabel 11 perhitungan untuk selisih medan magnet vertikal sejajar

\begin{tabular}{|c|c|c|c|c|c|}
\hline No & $x$ & $y$ & $x^{2}$ & $y^{2}$ & $x y$ \\
\hline 1 & 0,5 & -134 & 0,25 & 17956 & -67 \\
\hline 2 & 1 & -84 & 1 & 7056 & -84 \\
\hline
\end{tabular}




\begin{tabular}{|c|c|c|c|c|c|}
\hline 3 & 1,5 & -86 & 2,25 & 7396 & -129 \\
\hline 4 & 2 & -87 & 4 & 7569 & -174 \\
\hline Jumlah & $\sum x_{i}=5$ & $\sum y_{i}=-391$ & $\sum x_{i}^{2}=7,5$ & $\sum y_{i}^{2}=39977$ & $\sum x_{i} y_{i}=-454$ \\
\hline
\end{tabular}

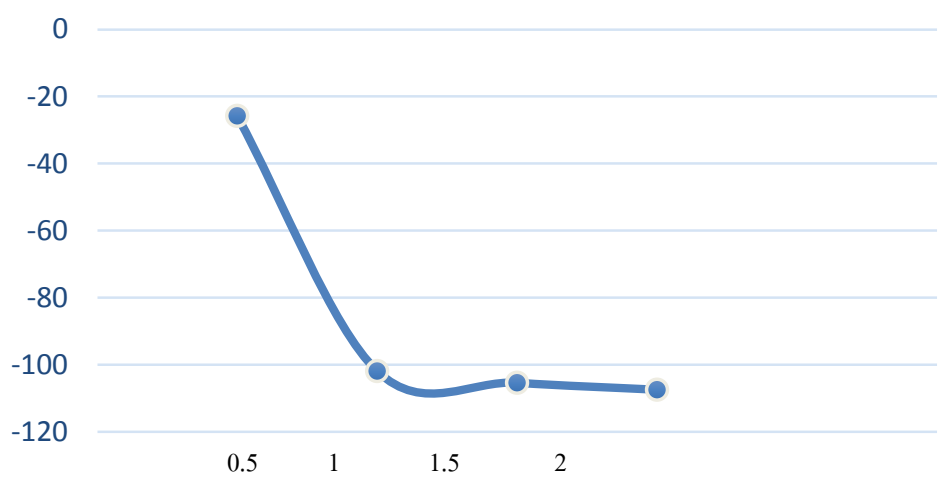

Grafik 1 Hubungan Antara Jarak dan Selisih Medan Magnet

Dari grafik 1 terlihat suat terlihat bentuk grafik eksponensial hubungan antara jarak dan selisih medan magnet dengan hubungan persamaan menurut Mogi(1962) dinyatakan dengan $y=a e^{b x}$ dengan $y=\Delta \gamma$ dan $x=r$, dan untuk mendapatkan nilai $a$ dan $b$ pada posisi seng horizontal maka digunakan persamaan berikut:

$y=a e^{b x}$ (persamaan ekponensial)

$\ln y=\ln a+b x \ln e$

$\ln y=\ln a+b x$

Dalam memperoleh nilai $a$ dan $b$ maka dilakukan proses linearisasi dengan $z=\ln y$, $p=\ln a$ atau $a=e^{p}$ dan $b=q$ sehingga bentuk persamaan menjadi :

$z=p+q x$

Untuk mendapatkan nilai $p$ dan $q$ terlebih dahulu kita menggunakan persamaan berikut:

$q=\frac{n \sum x_{i} y_{i-}\left(\sum x_{i}\right)\left(\sum y_{i}\right)}{n \sum x_{i}^{2}-\left(\sum x_{i}\right)^{2}}$

$p=\bar{y}-q \bar{x}$

Dalam mencari nilai $\bar{x}$ dan $\bar{y}$ maka digunakan persamaan:

$$
\begin{aligned}
& \bar{x}=\frac{1}{n} \sum x_{i} \\
& \bar{y}=\frac{1}{n} \sum y_{i}
\end{aligned}
$$


Nilai $p$ dan $q$ kemudian di subtitusikan kedalam persamaan 8 untuk mendapatkan nilai selisih medan magnet $(\Delta \gamma)$ terhadap jarak $(r)$ untuk tabel posisi seng horizontal dapat dilihat pada tabel 7 .

Tabel 12 selisih medan magnet $(\Delta \gamma)$ terhadap jarak $(r)$ Posisi Seng Horisontal

\begin{tabular}{|c|c|c|}
\hline No & $\mathrm{r}(\mathrm{m})$ & $\Delta \gamma_{\text {horizontal }}$ \\
\hline 1 & 0,5 & $1,84 \times 10^{-21}$ \\
\hline 2 & 1 & $3,21 \times 10^{-23}$ \\
\hline 3 & 1,5 & $5,59 \times 10^{-43}$ \\
\hline 4 & 2 & $9,73 \times 10^{-54}$ \\
\hline
\end{tabular}

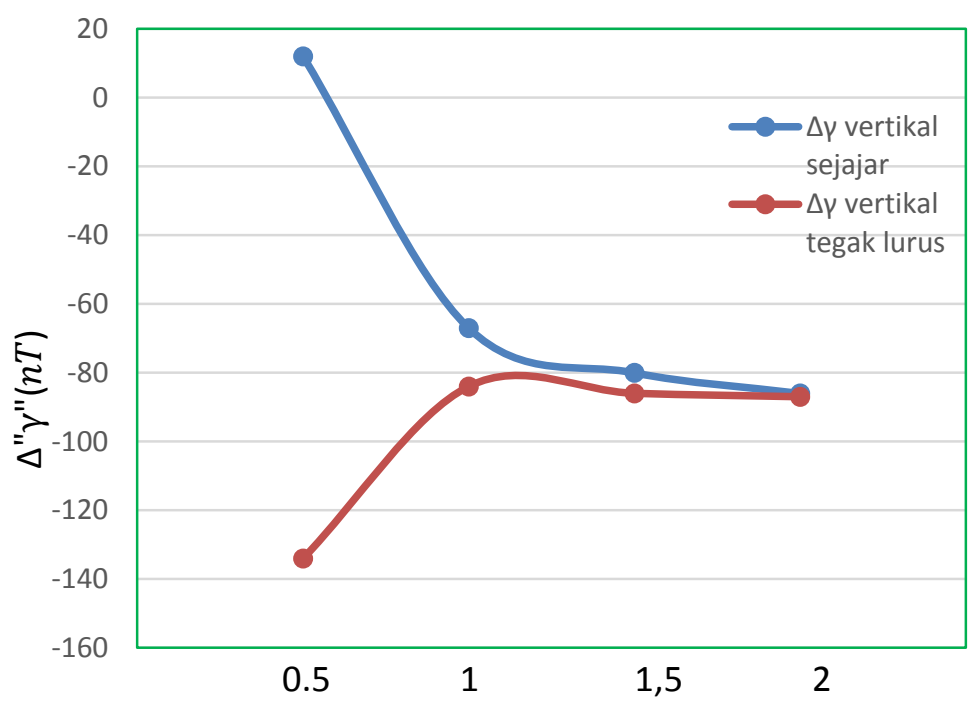

Grafik 2 Hubungan Jarak dan Selisih Medan Magnet

Dari grafik 2 juga terlihat suatu bentuk grafik eksponensial hubungan antara jarak dan selisih medan magnet dengan hubungan persamaan dengan $y=a e^{b x}$ untuk $\Delta \gamma_{\text {vertikal tegak lurus }}$ dan $y=a e^{-b x}$ untuk $\Delta \gamma_{\text {vertikal sejajar }}$ dengan $y=\Delta \gamma$ dan $x=r$. Untuk mendapatkan nilai $a$ dan $b$ pada posisi seng tegak lurus maka digunakan persamaan 8 sampai 15 sedangkan untuk posisi seng vertikal sejajar digunakan persamaan seperti berikut:

$y=a e^{-b x}$

$\ln y=\ln a-b x \ln e$

$\ln y=\ln a-b x$

Dalam memperoleh nilai $a$ dan $b$ maka dilakukan proses linearisasi dengan $z=\ln y$, $p=\ln a$ atau $a=e^{p}$ dan $b=q$ sehingga bentuk persamaan menjadi :

$z=p-q$

Untuk mendapatkan nilai $p$ dan $q$ terlebih dahulu kita menggunakan persamaan berikut: 
$q=\frac{n \sum x_{i} y_{i-}\left(\sum x_{i}\right)\left(\sum y_{i}\right)}{n \sum x_{i}^{2}-\left(\sum x_{i}\right)^{2}}$

$p=\bar{y}+q \bar{x}$

Dalam mencari nilai $\bar{x}$ dan $\bar{y}$ maka digunakan persamaan;

$\bar{x}=\frac{1}{n} \sum x_{i}$

$\bar{y}=\frac{1}{n} \sum y_{i}$

Nilai $p$ dan $q$ kemudian di subtitusikan kedalam persamaan 16 untuk mendapatkan nilai selisih medan magnet $(\Delta \gamma)$ terhadap jarak $(r)$ pada posisi seng vertical sejajar. Untuk tabel posisi seng vertical tegak lurus dan vertical sejajar dapat di lihat pada tabel berikut.

Tabel 13 Selisih Medan Magnet $(\Delta \gamma)$ terhadap Jarak $(r)$ Posisi Seng Vertikal Tegak Lurus

\begin{tabular}{|c|c|c|}
\hline No & $\mathrm{r}(\mathrm{m})$ & $\Delta \gamma_{\text {vertikal tegak lurus }}$ \\
\hline 1 & 0,5 & $52,54 \times 10^{-6}$ \\
\hline 2 & 1 & $31,68 \times 10^{-19}$ \\
\hline 3 & 1,5 & $18,66 \times 10^{-28}$ \\
\hline 4 & 2 & $11,18 \times 10^{-45}$ \\
\hline
\end{tabular}

Tabel 14 Selisih Medan Magnet $(\Delta \gamma)$ terhadap Jarak $(r)$ Posisi Seng Vertikal Sejajar

\begin{tabular}{|c|c|c|}
\hline No & $\mathrm{r}(\mathrm{m})$ & $\Delta \gamma_{\text {vertikal sejajar }}$ \\
\hline 1 & 0,5 & $39,84 \times 10^{-35}$ \\
\hline 2 & 1 & $33,12 \times 10^{-41}$ \\
\hline 3 & 1,5 & $27,36 \times 10^{-47}$ \\
\hline 4 & 2 & $23,4 \times 10^{-53}$ \\
\hline
\end{tabular}

\section{KESIMPULAN}

1. jarak mempengaruhi medan magnet lokal di BMKG Tondano, sehingga membentuk medan magnetik anomali.

2. Medan magnetic anomaly bahan seng tersbut dipengaruhi oleh parameter jarak, geometri bahan, dan keadaan lingkungan penelitian terhadap sumber medan magnet.

3. Seng hanya merupakan suatu media untuk mengetahui karakter dalam mendeteksi medan magnet yang sifatnya terinduksi oleh medan magnet lokal di BMKG Tondano.

4. Semakin jauh jarak suatu bahan seng dengan sumber medan magnet maka selisih terhadap medan magnet lokalnya akan semakin kecil atau perlahan-lahan akan hilang. 


\section{DAFTAR PUSTAKA}

Alonso, M., and Edward, J. F. 1992. Dasar-Dasar Fisika. Edisi Ke II jilid II. Erlangga. Jakarta.

Diktat pratikum. 1989. Kursus Pengukuran Dasar Geofisika Untuk Ekplorasi dan Geoteknik. Laboratorium Fisika Bumi- Jurusan Fisika ITB.Bandung.

Dobrin,M.B.1976. Introduction To Geophysichal prosfecting. Mc Graw_Hill New York, N.Y.

Efendi.2009. Interpretasi Data Anomali Total Intensitas Magnet bumi Badan Meteorologi Klimatologi dan Geofisika.

Grant, F.S. and West. 1965 Interpretation Theory in Apllied Geophisycs.

Haliday, D., Resnick.1996.Terjemahan Pantur Silaban Fisika Edisi Ke-3 jilid 2. Erlanggan.Jakarta

Mogi.1962. Pageoph Topical Vol.163 Computational.

Santoso, D., 2002. Pengantar Teknik Geofisika. Institut Teknologi Bandung.

Soedojo P.1999. Fisika Dasar. Andi. Yogyakarta

Telford W. M. Cs .1976.Apllied Geophysics.Cambridge University .

http://dlm.esdm.go.id/Kolokium2005/PanasBumi/SabangMakalahGeofisika.Bianacipta.B andung. Diakses: 20 Januari 2010, 18:49:47 